\title{
PENGARUH PENGETAHUAN PAJAK, PENGETAHUAN ZAKAT DAN SIKAP TERHADAP KEPATUHAN WAJIB PAJAK MUSLIM
}

\author{
Muhammad Yusuf ${ }^{1}$, Tubagus Ismail ${ }^{2}$ \\ Universitas Mercu Buana Jakarta \\ email : yoezoef_sukses@yahoo.com,adeismail73@gmail.com
}

\begin{abstract}
Abstrak. Sinergi peraturan perpajakan dan zakat yang tercantum dalam undang-undang Republik Indonesia nomor 38 tahun 1999 tentang pengelolaan zakat dan nomor 17 tahun 2000 tentang pajak penghasilan, dapat dilihat sebagai langkah maju dalam integrasi pajak dan zakat. Pengetahuan para wajib pajak Muslim tentang adanya sinergi ini penting untuk menumbuhkan perilaku yang obyektif yang dapat mempengaruhi sikap wajib pajak dalam menerapkan kepatuhan pajak dengan cara membuat zakat sebagai pengurang penghasilan kena pajak.

Tesis ini membahas pengaruh pengetahuan pajak, pengetahuan tentang zakat, dan kepatuhan kepatuhan pajak pembayar pajak muslim. Dalam hal ini, penulis memusatkan perhatian pada pengaruh langsung dan tidak langsung antara pengetahuan perpajakan, pengetahuan zakat, dan kepatuhan kepatuhan pajak pembayar pajak muslim.

Penelitian ini dilakukan terhadap 178 responden, yaitu pembayar pajak KPP Pratama Kota Depok, dengan mengambil sampel secara langsung di lapangan, dengan penggunaan kuesioner sebagai alat pendataan. Structural Equation Modeling (SEM) digunakan untuk analisis data, dengan menggunakan program SPLS 2.0.

Hasilnya menunjukkan bahwa ada pengaruh langsung pengetahuan perpajakan, pengetahuan zakat, dan kepatuhan kepatuhan pajak pembayar pajak muslim. Hasil penelitian juga menunjukkan pengaruh tidak langsung antara pengetahuan pajak, pengetahuan zakat, dan kepatuhan kepatuhan pajak wajib pajak muslim.
\end{abstract}

Kata Kunci: Pengetahuan Pajak, Wawasan Zakat, Teori Perilaku Terencana, Sikap, Kepatuhan dan Peraturan Pemerintah

\begin{abstract}
The synergy of tax and zakat regulation contained in the law of Republic Indonesia number 38 of 1999 on zakat management and number 17 of 2000 on income tax, can be seen as step forward in the integration of tax and zakat. The Muslim taxpayers' knowlegde about the existance of this synergy is important for cultivating obidient behaviour that can affect taxpayer's attitude in implementing tax compliance by making zakat as a deduction of taxable income.

This thesis disscusses the influences of tax knowledge, knowledge of zakat, and tax compliance attitude of muslim taxpayers. In this case, the author focuses on the direct and indirect influences between tax knowledge, knowledge of zakat, and tax compliance attitude of muslim taxpayers.

This research was conducted on 178 respondents, which are KPP Pratama taxpayers of the City of Depok, by taking samples directly in the field, with the use of questionaires as a data collection tool. Structural Equation Modeling (SEM) was used for data analysis, using the SPLS 2.0 program. The results showed that there is a direct influence of tax knowledge, knowledge of zakat, and tax compliance attitude of muslim taxpayers. The results also indicated the indirect influence between tax knowledge, knowledge of zakat, and tax compliance attitude of muslim taxpayers.
\end{abstract}

Key Words : Tax Knowledge, pengetahauan Zakat, Theory of Planned Behavior, Attitude, Tax Compliance and Government Regulation 
Muhammad Yusuf, Tubagus Ismail , Pengaruh Pengetahuan Pajak, Pengetahuan Zakat ...

\section{PENDAHULUAN}

Zakat merupakan harta yang wajib dibayarkan oleh setiap muslim yang telah memenuhi syarat, untuk diberikan kepada orang-orang yang berhak menerimanya. Subyek zakat yaitu orang Islam yang telah memenuhi nishab atas harta yang dimiliki dengan persyaratan seperti muslim (baligh), merdeka dan berakal, milik yang sempurna (legal secara hukum), cukup nishabnya. Sedangkan obyek zakat merupakan kekayaan atau penghasilan yang diperoleh kaum muslimin yang sudah mencapai pada nishabnya, sehingga ia wajib mengeluarkan sebagian dari harta tersebut dan memberikannya kepada orang-orang yang berhak menerimanya sesuai dengan syariat Islam.

Di Indonesia, seorang wajib zakat juga merupakan wajib pajak. Seandainya diminta untuk memprioritaskan, tentu masyarakat muslim lebih rela membayar zakat daripada pajak karena lebih didorong oleh motivasi beragama dan kesadaran atas imannya (Hafidhuddin, 2002).

Jika perintah zakat diatur dalam Al Qur'an dan Sunnah Rosul, kewajiban pajak bagi muslimin di Indonesia diatur dalam undang-undang perpajakan yaitu pada Undang-undang No. 28 Tahun 2007 Pasal 1 angka 1 tentang pengertian pajak yaitu "Kontribusi wajib kepada negara yang terutang oleh orang pribadi atau badan yang bersifat memaksa berdasarkan undangundang, dengan tidak mendapat imbalan secara langsung dan digunakan untuk keperluan negara bagi sebesar-besarnya kemakmuran rakyat".

Berdasarkan aturan-aturan tersebut seharusnya zakat dan pajak mempunyai dua fungsi yaitu pertama sebagai sumber pendapatan negara (budgeter) dan yang kedua sebagai alat pemindah kekayaan (regulator). Sehingga zakat dan pajak menjadi dua instrumen untuk memindahkan harta kekayaan, yaitu memindahkan harta dari orang kaya kepada orang miskin. Oleh karena itu, Cara memindahkan kekayaan dari orang kaya kepada orang miskin bagi muslimin adalah melalui zakat dan pajak.

Berdasarkan data Badan Amil Zakat
Nasional, penerimaan zakat pada tahun 2013 sebesar Rp. 3.279.627.462,-. Sedangkan penerimaan negara dari sektor pajak pada tahun 2013, laparoan keuangan Dirjen Pajak mencatat sebesar Rp. 921,40 triliun. Namun pencapaian tersebut masih berada di bawah target Anggaran Pendapatan Belanja Negara Perubahan (APBN-P) 2013 yang sebesar Rp. 1.148,4 triliun (http://www.ekon.go.id).

Dirjen Pajak pada tahun 2013 Sebesar 25.109.959 juta jiwa. Sedangkan jumlah pembayar zakat yang memiliki Nomor Pokok Wajib Zakat sekitar 19 Ribu Jiwa (ROL, Juni 2014). Fenomena diatas menunjukan adanya pandangan kewajiban berganda sebagai warga negara yang beragama muslim untuk mengeluarkan beberapa hartanya untuk membayar zakat dan pajak.

Beberapa penelitian mengenai zakat dan pajak terdapat research gap diantaranya seperti yang dikemukakan oleh Bakar (2010), bahwa zakat tampaknya tidak ditempatkan atau dianggap sebagai prioritas dibandingkan dengan perpajakan. Namun beberapa penelitian sebelumnya juga menemukan bahwa zakat lebih menjadi prioritas dibandingkan pajak (Hafidhuddin, 2002). Muktiyanto dan Hendrian (2008) dalam penelitiannya menghasilkan bahwa sebagian besar pembayar zakat juga membayar pajak. Namun lebih dari 50\% masyarakat yang membayar zakat tidak mengetahui bahwa zakat dapat sebagai pengurang penghasilan kena pajak, dan pembayaran zakat cenderung tidak melalui pengelola zakat yang telah ditunjuk oleh pemerintah.

Meskipun zakat belum dijadikan sumber penerimaan negara dan belum diurus oleh negara seperti halnya pajak, namun zakat sudah tercantum dalam peraturan perundangundangan di Indonesia, yaitu Undang-Undang Nomor 38 Tahun 1999 dan terakhir yang berlaku Undang-Undang Nomor 23 Tahun 2011 tentang pengelolaan zakat (Gusfahmi, 2007).

Aturan-aturan yang telah ditetapkan untuk masyarakat muslimin sebagai warga negara Indonesia memunculkan dilema antara prioritas untuk membayar zakat atau membayar pajak. Dualisme kewajiban pajak dan zakat tersebut telah diatur oleh 


\section{TRANSPARANSI}

Jurnal Ilmiah Ilmu Administrasi

ISSN 2085-1162

pemerintah dengan melakukan sinergi antara Undang-undang Nomor 38 tahun 1999 tentang pengelolaan zakat dengan Undangundang Nomor 17 tahun 2000 tentang pajak penghasilan, dengan mengakui zakat sebagai pengurang penghasilan kena pajak. Hal tersebut didukung dengan dikeluarkannya Undang-Undang Nomor 36 Tahun 2008 serta diatur dalam Peraturan Direktur Jenderal Pajak Nomor PER-6/PJ/2011 tentang pelaksanaan pembayaran dan pembuatan bukti pembayaran atas zakat atau sumbangan keagamaan yang sifatnya wajib yang dapat dikurangkan dari penghasilan bruto.

Adanya aturan mengenai zakat sebagai pengurang penghasilan kena pajak seperti yang tercantum dalam Undang-Undang Nomor 38 Tahun 1999 dan Undang-Undang Nomor 17 Tahun 2000, menjelaskan bahwa zakat penghasilan dapat diakui sebagai pengurang penghasilan kena pajak harus memenuhi beberapa persyaratan yang bersifat kumulatif dan harus dilaporkan dalam laporan pajak penghasilan tahunan yaitu:

1. Zakat harus nyata-nyata dibayarkan oleh wajib pajak orang pribadi pemeluk Islam dan atau wajib pajak badan dalam negeri yang dimiliki oleh pemeluk agama Islam

2. Zakat Dibayarkan kepada badan amil zakat atau lembaga amil zakat yang dibentuk atau disahkan oleh pemerintah.

3. Zakat yang dibayar adalah zakat yang berkenaan dengan penghasilan yang menjadi obyek pajak.

Penetapan Undang-undang Nomor 38 tahun 1999 tentang Pengelolaan Zakat, dan Undang-undang Nomor 17 Tahun 2000 tentang Pajak Penghasilan oleh pemerintah merupakan wujud sinergi antara zakat dan pajak. Pemberlakuan zakat penghasilan sebagai pengurang penghasilan kena pajak akan mempengaruhi penerimaan pemerintah dari sektor pajak. Karena zakat yang dibayarkan oleh wajib pajak muslim akan mengurangi jumlah penghasilan kena pajaknya. Sehingga apabila penghasilan kena pajak menjadi kecil maka pajak penghasilan yang diterima oleh negara juga mengecil.

Pengetahuan wajib pajak muslim mengenai perpajakan dan zakat menjadi dasar dalam menyikapi UU Nomor 38 Tahun 1999 dan UU No. 17 Tahun 2000. Kendala yang terjadi dalam hal implementasi UU Nomor 38 Tahun 1999 dan UU No. 17 Tahun 2000 yaitu potensi munculnya jumlah pajak yang lebih bayar ditanggung oleh wajib pajak muslim atas pajak yang telah dipotong pemberi kerja (Soepatmo, 2001). Namun demikian, menurut Fitranoska (2006) terdapat juga manfaat yang diperoleh dari penerapan UU Nomor 38 Tahun 1999 dan UU No. 17 Tahun 2000, yaitu dapat memacu semangat wajib pajak muslim untuk membayar zakat penghasilannya melalui lembaga yang ditunjuk oleh pemerintah. Sehingga Dirjen Pajak selaku wakil pemerintah dapat menjaring masyarakat yang sudah membayar zakat, tetapi belum menjadi wajib pajak. Begitu pula yang dilakukan oleh Baznas, dapat menggunakan data Dirjen Pajak untuk mensosialisasikan bahwa membayar zakat dapat mengurangi pajak. Sehinga dengan demikian akan terbangun sinergi dan kesadaran dari wajib pajak muslim untuk membayar pajak dan zakatnya.

Sikap yang terbentuk dari pengetahuan dan pemahaman kepada faktor-faktor dilingkungannya akan mempengaruhi seseorang untuk bertindak apakah patuh atau mengelak untuk membayar pajak. Secara teoritis, perilaku merupakan sikap seseorang terhadap suatu objek yang dapat mempengaruhinya dalam membuat keputusan (Mueller 1986). Kepatuhan wajib pajak muslim terhadap pelaksanaan peraturan perpajakan dan zakat yang telah bersinergi dalam UU Nomor 38 Tahun 1999 dan UU No. 17 Tahun 2000 tergantung dari sikap wajib pajak muslim dalam mengimplementasikan pengetahuaannya yaitu dengan menjadikan zakat sebagai pengurang penghasilan kena pajak.

Penelitian-penelitian

mengenai keterkaitan antara zakat dan pajak belum banyak dilakukan, terutama mengenai pengetahuan wajib pajak muslim dalam menyikapi UU Nomor 38 Tahun 1999 Tentang Pengelolaan Zakat dan UU Nomor 
Muhammad Yusuf, Tubagus Ismail , Pengaruh Pengetahuan Pajak, Pengetahuan Zakat ...

17 Tahun 2000 Tentang Pajak Penghasilan terhadap kepatuhan pajak. Hal ini menjadi dasar ketertarikan untuk meneliti mengenai pengetahuan dan sikap wajib pajak muslim terhadap kepatuhan pajak.

Sasaran penelitian ini difokuskan pada wajib pajak orang pribadi di Kota Depok Jawa Barat. Sebagai kota yang mayoritas penduduknya beragama Islam, sebagian WP di Kota Depok adalah pemeluk agama Islam dengan jumlah persentase sebesar 92\% dari total keseluruhan penduduk Kota Depok. Para WP yang dimaksud juga mempunyai kewajiban lain yang harus ditunaikan, yaitu membayar zakat. Besarnya jumlah penduduk Kota Depok merupakan ladang yang besar bagi pendapatan pajak. Selain itu Islam sebagai agama mayoritas di Depok juga merupakan ladang bagi penerimaan Zakat di Kota Depok.

Penelitian dilakukan untuk mengetahui pengetahuan dan sikap warga Kota Depok terhadap sinergi peraturan perpajakan dan zakat. Pengetahuan dan sikap warga Kota Depok menjadi alat ukur untuk mengetahui kepatuhan pajak yang dilaksanakan oleh warga Kota Depok.

Berdasarkan latar belakang, penulis merumuskan masalah sebagai berikut:

1. Apakah pengetahuan wajib pajak muslim tentang perpajakan berpengaruh terhadap kepatuhan pajak ?

2. Apakah pengetahuan wajib pajak muslim tentang zakat berpengaruh terhadap kepatuhan pajak ?

3. Apakah sikap wajib pajak muslim berpengaruh terhadap kepatuhan Pajak?

4. Apakah pengetahuan perpajakan berpengaruh terhadap sikap wajib pajak muslim?

5. Apakah pengetahuan zakat berpengaruh terhadap sikap wajib pajak muslim ?

\section{Tujuan dan Kontribusi Penelitian}

Tujuan peneltian ini untuk mengetahui dan membuktikan secara empiris pengetahuan perpajakan, pengetahuan zakat dan sikap terhadap kepatuhan wajib pajak muslim serta pengaruh pengetahuan pajak dan pengetahuan zakat terhadap sikap wajib pajak muslim.

Penelitian ini diharapkan dapat memberikan kontribusi bagi masyarakat berupa pengetahuan dan pemahaman mengenai pelaksanaan aktivitas pajak dan zakat mulai dari perhitungan, pembayaran zakat dan pajak sampai dengan proses pelaporan.

Penelitian ini juga diharapakan memberikan kontribus bagi negera khususnya dalam meningkatkan pendapatan negara dari pembayaran zakat dan pajak dari masyarakat muslim di Indonesia.

\section{TELAAH LITERATUR DAN PENGEMBANGAN HIPOTESIS}

\section{Pengetahuan Pajak}

Pengetahuan perpajakan adalah pengetahuan mengenai konsep ketentuan umum di bidang perpajakan, jenis pajak yang berlaku di Indonesia mulai dari subyek pajak, obyek pajak, tarif pajak, perhitungan pajak terutang, pencatatan pajak terutang, sampai dengan bagaimana pengisian pelaporan pajak. Pengetahuan perpajakan ini tidak hanya pemahaman konseptual berdasarkan UndangUndang Perpajakan, Keputusan Menteri Keuangan, Surat Edaran, Surat keputusan tetapi juga adanya tuntutan kemampuan atau ketrampilan teknis bagaimana menghitung besarnya pajak yang terutang (Supriyati, 2009).

Terdapat beberapa indikator wajib pajak mengetahui dan memahami peraturan perpajakan, yaitu: (1) Kepemilikan NPWP, setiap wajib pajak yang memiliki penghasilan wajib untuk mendaftarkan diri untuk memperoleh NPWP sebagai salah satu sarana untuk pengadministrasian pajak. Pengetahuan dan pemahaman mengenai hak dan kewajiban sebagai wajib pajak. Apabila wajib pajak telah mengatahui kewajibannya sebagai wajib pajak, maka mereka akan melakukannya, salah satunya adalah membayar pajak. (3) Pengetahuan dan pemahaman mengenai sanksi perpajakan. Semakin tahu dan paham wajib pajak terhadap peraturan perpajakan, maka semakin tahu dan paham pula wajib pajak terhadap sanksi yang akan diterima bila melalaikan kewajiban perpajakan mereka. Hal ini tentu akan mendorong setiap wajib pajak yang taat 


\section{TRANSPARANSI}

Jurnal Ilmiah Ilmu Administrasi

ISSN 2085-1162

akan menjalankan kewajibannya dengan baik. (4) Pengetahuan dan pemahaman mengenai PTKP, PKP, dan tarif pajak. Dengan mengetahui dan memahami mengenai tarif pajak yang berlaku, maka akan dapat mendorong wajib pajak untuk dapat menghitung kewajiban pajak sendiri secara benar. (5) Wajib pajak mengetahui dan memahami peraturan perpajakan melalui sosialisasi yang dilakukan oleh KPP. (6) Wajib pajak mengetahui dan memahami peraturan pajak melalui training perpajakan yang mereka ikuti (Widayawati dan Nurlis; 2010).

\section{Pajak Dalam Perspektif Islam}

Pengertian pajak menurut Qardhawi (2011) adalah kewajiban yang ditetapkan terhadap wajib pajak, yang harus disetorkan kepada negara sesuai dengan ketentuan, tanpa mendapat prestasi kembali dari negara, dan hasilnya untuk membiayai pengeluaranpengeluaran umum di satu pihak dan untuk merealisasi sebagai tujuan ekonomi, sosial, politik dan tujuantujuan lain yang ingin dicapai oleh negara.

Qardhawi (2011) menguraikan diwajibkannya pajak yang adil setelah zakat, sebagai berikut:

a. Solidaritas sosial/jaminan merupakan

kewajiban, kesepakatan tentang

kewajiban kepada kaum muslimin sesudah zakat apabila ada kebutuhan yang perlu ditanggulangi bersama.

b. Sasaran zakat hanya terbatas pada 8 asnaf sementara pembiayaan negara lebih banyak jenisnya, misalnya pembangunan sarana-prasarana transportasi, bangunan dan fasilitas umum. Distribusi zakat terbatas, kecuali pendapat bahwa fi sabilillah mencakup segala kepentingan dan urusan, sementara para ahli fiqih tidak memperbolehkan untuk mencampuradukkan harta zakat dengan sumber lainnya

c. Kerugian dibalas dengan keuntungan, adanya asas timbal balik turut serta membiayai keperluan umum yang manfaatnya kembali kepada anggota
Volume 9, Nomor 02, September 2017

masyarakat dalam berbagai bentuk fasilitas, pelayanan dan perlindungan.

Chapra (2001) menjelaskan apabila sumber-sumber penerimaan negara sudah tidak mencukupi, maka negara dapat memungut dana pajak dari masyarakat untuk memenuhi kepentingan masyarakat yang lebih luas. Mazhab fiqih pun sepakat membela hak negara Islam untuk meningkatkan pemasukan lewat pajak sehingga memungkinkan pelaksanaan fungsi yang efektif.

\section{Pengetahuan Zakat}

Pengetahuan pada hakikatnya merupakan segenap apa yang kita ketahui tentang suatu objek termasuk ke dalamnya adalah ilmu (Jujun, 1993). Lebih lanjut Jujun (1993) menyatakan bahwa terdapat dua cara yang pokok bagi manusia untuk mendapatkan pengetahuan yang benar. Cara pertama adalah mendasarkan diri pada rasio, dan yang kedua secara sederhana mendasarkan diri kepada pengalaman.

Kesedian membayar zakat merupakan sebuah keharusan bagi orang Islam. Sudah menjadi pengetahuan umum bahwa membayar zakat merupakan kewajiban bagi setiap orang Islam. Oleh karena itu orang Islam perlu memiliki pengetahuan tentang zakat.

Berdasarkan Undang-undang No. 38 Tahun 1999 Tentang Pengelolaan zakat, zakat adalah Zakat adalah harta yang wajib disisihkan oleh seorang muslim atau badan yang dimiliki oleh orang muslim sesuai dengan ketentuan agama untuk diberikan kepada yang berhak menerimanya.

Dewan Syariah Lazis Muhammadiyah (2004:18) mengutarakan syarat-syarat harta kekayaan yang wajib dizakati adalah sebagai berikut: (1) Milik penuh; pemilik harta tersebut memungkinkan untuk menggunakan dan mengambil manfaatnya secara penuh.(2) Berkembang; harta tersebut dapat bertambah atau berkembang bila diusahakan atau mempunyai potensi untuk berkembang. (3) Cukup nisab; hartanya telah mencapai jumlah tertentu sesuai ketetapan syara'. (4) Sisa hutang; orang yang mempunyai hutang 
Muhammad Yusuf, Tubagus Ismail , Pengaruh Pengetahuan Pajak, Pengetahuan Zakat ...

sebesar uang atau harta yang dimilikinya, maka harta tersebut terbebas dari zakat. (5) Berlalu satu tahun; kepemilikan harta tersebut sudah berlalu masanya selama 12 bulan.

Pelaksanaan zakat masih menemui hambatan dikarenakan kesadaran masyarakat muslim dalam pelaksanaan zakat masih belum diikuti dengan tingkat pengetahuan yang memadai tentang zakat. Kurangnnya pengetahuan tentang jenis harta yang wajib untuk dizakatkan dan mekanisme pembayaran zakat yang sesuai dengan syariat Islam mempengaruhi pembayaran zakat yang dilakukan oleh masyarakat muslim.

\section{Sikap}

Kata sikap berasal dari bahasa Inggris yaitu attitude yang diartikan sebagai sikap terhadap objek tertentu, atau sikap perasaan, sikap pandangan, sikap perasaan, yang disertai dengan kecenderungan untuk bertindak dan berperilaku sesuai dengan sikap tersebut. Sedangkan menurut Ismail \& Zein (2008) sikap berasal dari bahasa latin yaitu aptus yang berarti sesuai atau cocok dan siap untuk bertindak atau berbuat sesuatu.

Gerungan (2004) menyebutkan bahwa attitude adalah sikap dan kesediaan untuk bereaksi terhadap suatu hal tertentu. Dan Ajzen (2005) menyatakan bahwa sikap adalah evaluasi seseorang baik secara positif maupun negatif terhadap suatu benda, orang, kejadian, perilaku dan minat tertentu. Sedangkan Dayakisni \& Hudaniah (2013) menyatakan bahwa sikap merupakan suatu keadaan yang memungkinkan timbulnya suatu perbuatan dan perilaku.

Perubahan sikap pada dasarnya akan dimulai dengan proses pengambilan keputusan yang didahului oleh proses analisa dalam diri tiap individu atau lembaga (dalam hal ini pengelola atau lembaga zakat dan pajak). Analisis tersebut memerlukan waktu yang cukup sebagai tahap mempertimbangkan melalui proses persepsi terhadap segala aspek. Proses persepsi, sebagaimana proses sikap dipengaruhi oleh faktor pribadi (kepribadian) dan faktor sosial (Rivai, 2009).

\section{Kepatuhan Pajak}

Dalam Kamus umum Bahasa Indonesia, kepatuhan berarti tunduk atau patuh pada ajaran atau aturan. Menurut Gibson (1991) kepatuhan adalah motivasi seseorang, kelompok atau organisasi untuk berbuat atau tidak berbuat sesuai dengan aturan yang ditetapkan. Dalam pajak aturan yang berlaku adalah Undang-undang perpajakan sehingga dapat disimpulkan bahwa kepatuhan pajak adalah kepatuhan wajib pajak terhadap undang-undang perpajakan.

Definisi kepatuhan dalam kaitannya dengan Wajib Pajak adalah perilaku wajib pajak dalam memenuhi kewajiban perpajakannya sesuai dengan peraturan yang berlaku. Sedangkan menurut Fronzoni (1999) menyatakan bahwa kepatuhan dalam hukum pajak memiliki arti umum sebagai (1) melaporkan secara benar dasar pajak, (2) memperhitungkan secara benar kewajiban, (3) tepat waktu dalam pelaporan pajak , (4) tepat waktu membayar jumlah pajak terutang.

Instrumen kepatuhan pajak dapat dilihat melalui 3 (tiga) indikator kepatuhan: pertama, kepatuhan pengisian SPT (filling compliance), yaitu kepatuhan dalam menyerahkan surat pemberitahuan baik tahunan dan masa dengan tepat waktu. Kedua, kepatuhan pembayaran (payment compliance), yaitu kepatuhan dalam melakukan pembayaran pajak terhutang dengan tepat waktu. Ketiga, kepatuhan pelaporan (reporting compliance), yaitu kepatuhan dalam melaporkan seluruh pajak yang terhutang (Mustikasari: 2007). Kepatuhan pengisian SPT dan kepatuhan pembayaran merupakan kepatuhan dalam memenuhi kewajiban perpajakan secara formal, sedangkan kepatuhan pelaporan merupakan kepatuhan secara material.

\section{Penelitian Terdahulu}

Banyak Penelitan mengenai pengaruh pengetahuan terhadap kepatuhan pajak dan kepatuhan zakat. Pengetahuan wajib pajak tentang pajak adalah proses pengubahan sikap dan tata laku seorang wajib pajak atau kelompok wajib pajak dalam usaha mendewasakan manusia melalui upaya pengajaran dan pelatihan. Muarifah (2013) dalam penelitiannya menyimpulkan bahwa pengetahuan pajak, kualitas pelayanan petugas pajak dan sikap wajib pajak 


\section{TRANSPARANSI}

Jurnal Ilmiah Ilmu Administrasi

ISSN 2085-1162

berpengaruh positif terhadap kepatuhan wajib pajak.

Fallan (2009) mengungkapkan bahwa perubahan sikap wajib pajak dipengaruhi oleh pengetahuan pajak yang lebih baik. Aspek pengetahuan perpajakan bagi wajib pajak sangat mempengaruhi sikap wajib Pajak terhadap system perpajakan yang adil. Dengan kualitas pengetahuan yang semakin baik akan memberikan sikap memenuhi kewajiban dengan benar melalui adanya system perpajakan suatu Negara yang dianggap adil. Dengan meningkatnya pengetahuan perpajakan masyarakat melalui pendidikan perpajakan baik formal maupun non formal akan berdampak positif terhadap pemahaman dan kesadaran Wajib Pajak dalam membayar pajak.

Yulianawati (2011) menyatakan bahwa pengetahuan peraturan perpajakan tidak berpengaruh terhadap kemauan membayar pajak. Hal ini berarti bahwa pendidikan yang diterima oleh wajib pajak tidak menjamin seorang wajib pajak akan lebih menyadari akan kemauan membayar kewajiban perpajakannya.

Pengetahuan dan Pemahaman wajib pajak tentang peraturan perpajakan dapat mempengaruhi kepatuhan pembayaran pajak. Pengetahuan dan pemahaman tentang peraturan perpajakan akan meningkatkan kemauan wajib pajak untuk membayar pajak, karena wajib pajak yang memiliki pengetahuan peraturan perpajakan berpikir lebih baik membayar daripada terkena sanksi (Widayati dan Nurlis, 2010).

Witono (2008) melakukan penelitian terhadap wajib pajak orang pribadi di KPP Surakarta dan konsultan pajak di wilayah Surakarta menghasilkan kesimpulan bahwa semakin baik pengetahuan wajib pajak dan konsultan pajak terhadap peraturan pajak maka semakin tinggi tingkat kepatuhan wajib pajak, dan pengetahuan pajak dan keadilan sistem pajak baik bersama-sama maupun sendiri-sendiri berpengaruh yang signifikan terhadap kepatuhan wajib dan konsultan pajak.

Nugroho (2012), melakukan penelitian
Volume 9, Nomor 02, September 2017

mengenai faktor-faktor yang mempengaruhi kemauan membayar pajak studi kasus pada wajib pajak orang pribadi yang terdaftar di KPP Pratama Semarang Tengah Satu menghasilkan kesimpulan bahwa pengetahuan dan pemahaman peraturan perpajakan, pelayanan fiskus yang berkualitas, dan persepsi terhadap efektivitas perpajakan berpengaruh signifikan terhadap kesadaran membayar pajak.

Kesedian membayar zakat merupakan sebuah keharusan bagi orang Islam. Sudah menjadi pengetahuan umum bahwa membayar zakat merupakan kewajiban bagi setiap orang Islam. Oleh karena itu orang Islam perlu memiliki pengetahuan tentang zakat. Idris dan Ayob (2001), menyatakan bahwa sikap muzakki dipengaruhi oleh gender, usia, persepsi tentang hukum zakat, pengetahuan, kualitas pelayanan, promosi atau sosialisasi zakat.

Kamil (2005) dalam studinya mengungkapkan bahwa persepsi kualitas layanan, tingkat pengetahuan zakat, dan promosi kampanye zakat, secara signifikan berhubungan dengan perilaku kepatuhan dalam arah yang positif.

Penjelasan mengenai Undang-undang No. 38 tahun 1999 Tentang Pengelolaan Zakat Pasal 14 ayat 3 yaitu Pengurangan zakat dari laba/pendapatan sisa kena pajak dimaksudkan agar wajib pajak tidak terkena beban ganda, yakni kewajiban membayar zakat dan pajak. Kesadaran membayar zakat dapat memacu kesadaran membayar pajak.

Pengetahuan mengenai zakat, seperti regulasi pemerintah mengenai perpajakan dan zakat tercantum di UU Nomor 38 Tahun 1999 mengenai zakat sebagai pengurang penghasilan kena pajak, dapat mempengaruhi kepatuhan pajak. setiap wajib pajak muslim akan dapat memanfaatkan peraturan tersebut untuk mengurangi jumlah penghasilan kena pajak dalam pelaporan pajaknya. Seperti yang diungkapkan oleh Fitranoska (2006) dalam penelitiannya ditemukan hubungan positif yang kuat antara Zakat sebagai pengurang Penghasilan Kena Pajak dengan pemenuhan kewajiban pajak. Sedangkan Buchori 
Muhammad Yusuf, Tubagus Ismail , Pengaruh Pengetahuan Pajak, Pengetahuan Zakat ...

mengungkapkan bahwa Faktor pendidikan, agama, kesadaran, Undang-undang dan peraturan serta faktor lingkungan dan sikap fiskus mempengaruhi kepatuhan wajib pajak, tetapi wajib pajak tidak patuh dalam implementasi zakat sebagai pengurang pajak terutangnya di SPT.

\section{Pengembangan Hipotesis}

\section{Pengetahuan wajib pajak muslim tentang perpajakan berpengaruh positif terhadap kepatuhan pajak.}

Tingkat kepatuhan wajib pajak dapat dipengaruhi beberapa faktor, diantaranya adalah pengetahuan pajak (Dewi, 2011). Pengetahuan pajak berpengaruh terhadap kepatuhan wajib pajak. Pengetahuan pajak diterapkan untuk membantu meningkatkan kepatuhan wajib pajak (Dian, 2014). Pengetahuan wajib pajak berkaitan dengan kedisiplinan wajib pajak dalam membayarkan pajaknya, karena kedisiplinan berdasar pada tingkat pemahaman yang sesuai terhadap hukum pajak yang dianut suatu negara serta sanksi-sanksi yang menyertainya (Hidayati, 2010).

Wajib Pajak yang tidak memiliki pengetahuan pajak tidak dapat memahami ketentuan perpajakan dengan baik tentunya akan salah dalam melakukan perhitungan pajak. Perhitungan pajak yang tidak sesuai dengan ketentuan perpajakan mengakibatkan nilai yang dilaporkan dalam Surat Pemberitahuan (SPT) tidak benar, sehingga Wajib Pajak sudah dianggap tidak patuh. Terlihat bagaimana pengetahuan pajak sangat mempengaruhi kepatuhan Wajib Pajak.

Berdasarkan teori dan bukti empiris di atas, dapat dikembangkan hipotesis sebagai berikut:

H1: Pengetahuan wajib pajak muslim tentang perpajakan berpengaruh positif terhadap kepatuhan pajak.

Pengetahuan wajib pajak muslim tentang zakat berpengaruh positif terhadap kepatuhan pajak.

UU No 38 tahun 1999 menyebutkan bahwa zakat yang telah dibayarkan kepada BAZ atau LAZ dapat dikurangkan terhadap laba/pendapatan sisa kena pajak dari wajib pajak yang bersangkutan. Hal tersebut menjelaskan bahwa zakat atas penghasilan yang nyata-nyata dibayarkan secara resmi oleh wajib pajak orang pribadi pemeluk Islam atau wajib pajak badan dalam negeri yang dimiliki kaum Muslim, dapat dikurangkan atas penghasilan kena pajak.

Salah satu cara untuk mengimplementasikan asas keadilan pada zakat sebagai pengurang $\mathrm{PPh}$ yaitu dengan melakukan penghitungan pajak terutang pada PPh.

Fitrasnoka (2006) dalam penelitiannya menjelaskan Terdapat hubungan positif yang kuat antara Zakat sebagai pengurang Penghasilan Kena Pajak dengan pemenuhan kewajiban pajak.

Berdasarkan teori, penjelasan, dan bukti empiris di atas, dikembangkan hipotesis sebagai berikut :

H2: Pengetahuan wajib pajak muslim tentang zakat berpengaruh positif terhadap kepatuhan pajak.

\section{Ada pengaruh sikap wajib pajak muslim} terhadap kepatuhan pajak.

Sikap merupakan determinan perilaku, sebab sikap berkaitan dengan persepsi, kepribadian maupun motivasi. Sikap dapat mencerminkan pengalaman yang menyenangkan atau tidak menyenangkan, beserta harapan terhadap pengalaman di masa depan. Sikap merupakan pernyataan atau pertimbangan evaluative, baik yang menguntungkan atau tak menguntungkan mengenai objek, orang atau peristiwa. Sikap dapat mencerminkan bagaimana seseorang dapat merasakan sesuatu (Yadyana dan Sudiksa, 2011).

Sikap mempunyai peran yang penting dalam menjelaskan perilaku seseorang dalam lingkungannya, walaupun masih banyak faktor lain yang mempengaruhi perilaku, seperti stimulus, latar belakang individu, motivasi, dan status kepribadian. Secara timbal balik, faktor lingkungan juga mempengaruhi sikap dan perilaku (Mustikasari, 2007). Muarifah (2013) dalam penelitiannya menyimpulkan bahwa pengetahuan pajak, kualitas pelayanan 
TRANSPARANSI

Jurnal Ilmiah Ilmu Administrasi

ISSN 2085-1162

petugas pajak dan sikap wajib pajak berpengaruh positif terhadap kepatuhan wajib pajak.

Berdasarkan uraian tersebut maka dirumuskan hipotesis sebagai berikut :

H3: Sikap wajib pajak muslim berpengaruh terhadap kepatuhan pajak

\section{Pengetahuan pajak mempengaruhi sikap wajib pajak muslim}

Sikap terhadap kepatuhan pajak adalah seberapa besar keyakinan wajib pajak atas hasil yang akan diperoleh dan evaluasi atas kepatuhan pajak. Sikap terhadap kepatuhan pajak dibentuk oleh keyakinan-keyakinan wajib pajak tentang kepatuhan pajak yang meliputi segalah hal yang diketahui, diyakini dan dialami wajib pajak mengenai pelaksanaan peraturan pajak. Fallan (2009) mengungkapkan bahwa perubahan sikap wajib pajak dipengaruhi oleh pengetahuan pajak yang lebih baik. Aspek pengetahuan perpajakan bagi wajib pajak sangat mempengaruhi sikap wajib Pajak terhadap system perpajakan yang adil. Dengan kualitas pengetahuan yang semakin baik akan memberikan sikap memenuhi kewajiban dengan benar melalui adanya system perpajakan suatu Negara yang dianggap adil. Dengan meningkatnya pengetahuan perpajakan masyarakat melalui pendidikan perpajakan baik formal maupun nonformal akan berdampak positif terhadap pemahaman dan kesadaran Wajib Pajak dalam membayar pajak.

Berdasarkan uraian tersebut maka dirumuskan hipotesis sebagai berikut :

H4: Pengetahuan pajak berpengaruh terhadap sikap wajib pajak muslim

\section{Pengetahuan Zakat mempengaruhi sikap wajib pajak muslim}

Seorang Muslim haruslah mengetahui tentang zakat. Para muzakki termotivasi untuk membayar zakat dipengaruhi oleh tingkat pengetahuan zakatnya. Meningkatnya pengetahuan zakat seseorang tergantung dari tingkat pembelajaran seseorang terhadap zakat. Menurut Kotler (2005: 217) pembelajaran meliputi perubahan prilaku seseorang yang timbul dari pengalaman. Sebagaian besar prilaku manusia adalah hasil belajar. Semakin baik pengetahuan zakat para muzakki dapat menigkatkan kesadaran mereka dalam membayar zakat yang menjadi pendorong yang kuat dan motivasi serta kontribusi yang positif bagi penerima zakat (suprayogi, 2011).

Pengetahuan yang cukup tentang zakat akan berdampak pada sikap muzakki untuk membayar zakat secara benar. seseorang yang telah menunjukkan sikap yang positif akan melakukan perbuatan yang mencerminkan sikap positifnya tersebut, misalnya dengan membayar pajak dan zakat tepat waktu dan sesuai ketentuan. Idris dan Ayob (2001), menyatakan bahwa sikap muzakki dipengaruhi oleh gender, usia, persepsi tentang hukum zakat, pengetahuan, kualitas pelayanan, promosi atau sosialisasi zakat.

Berdasarkan uraian tersebut maka dirumuskan hipotesis sebagai berikut : H5: Pengetahuan zakat berpengaruh terhadap sikap wajib pajak muslim

\section{METODE PENELITIAN}

\section{Jenis Penelitian}

Penelitian ini merupakan penelitian untuk menguji hipotesis (hypothesis testing) bertipe penelitian kausal yang bertujuan untuk meneliti hipotesis yang sudah dijelaskan sebelumnya yaitu tentang pengaruh dari pengetahuan dan sikap wajib pajak muslim terhadap kepatuhan pajak.

Untuk tujuan ini, penelitian akan dilakukan dengan melakukan survei lapangan yaitu penelitian dengan mengambil sampel dilapangan secara langsung dari suatu populasi dan menggunakan kuesioner sebagai alat pengumpulan data.

\section{Definisi dan Operasionalisasi Variabel}

Instrumen yang digunakan untuk mengukur variabel pada penelitian ini adalah instrument yang digunakan oleh penelitian sebelumnya dengan sedikit modifikasi. 
Muhammad Yusuf, Tubagus Ismail , Pengaruh Pengetahuan Pajak, Pengetahuan Zakat ...

Instrumen yang dipergunakan sebagian besar telah diuji reabilitas dan validitasnya. Responden akan diminta untuk menjawab pertanyaan dan pernyataan yang tercantum oleh kuesioner. Variabel pengetahuan pajak, pengetahuan zakat dan sikap merupakan variabel independen dan variabel kepatuhan pajak merupakan variabel dependen dimana variabel-variabel tersebut diukur dengan menggunakan skala 1-7 dari likert. Pemberian skor pada jawaban responden tergantung pada sifat pernyataan.

\section{Pengukuran Variabel}

Dalam penelitian ini dilakukan dua jenis pengukuran variabel, yaitu:

1) Skala nominal, untuk mengukur klasifikasi identitas profil responden seperti usia, pendidikan formal terakhir, jenis kelamin, lama memiliki NPWP dan lama menjalankan profesi.

2) Skala interval, untuk mengukur variabel dependen dan independen yaitu persepsi kontrol perilaku, pengetahuan pajak, persepsi keadilan pajak dan kepatuhan pajak dengan menggunakan skala linkert yaitu skor $1-7$.

\section{Populasi dan Sampel}

Populasi pada penelitian ini adalah Wajib Pajak Orang pribadi yang beragama Islam yang berpotensi membayar pajak dan zakat dan berada di wilayah KPP Depok Jawa Barat.

Penelitian ini menggunakan metode convenience sampling dan berdasarkan anggota populasi yang kami temui di lapangan pada saat anggota populasi melaporkan SPT di KPP Depok Jawa Barat yang bersedia menjadi responden dan dijadikan sampel sebanyak 178 wajib pajak.

\section{Teknik Pengumpulan Data}

Metode pengumpulan data primer dilakukan dengan menggunakan metode survei, metode ini dilakukan untuk mendapatkan data tentang indikator indikator dari konstruk- konstruk yang sedang diteliti dalam penelitian ini. Dalam proses pengumpulan data, peneliti akan memberikan kuesioner kepada Wajib Pajak orang pribadi yang melakukan kegiatan usaha atau pekerjaan bebas yang sedang menyampaikan SPT Masa di KPP dan dijadikan responden. Survei dilakukan pada rentang waktu antara bulan Februari 2015 sampai dengan April 2015.

\section{Metode Analisis}

Penelitian ini menggunakan teknik analisis dengan pendekatan Structural Equation Modeling (SEM) variance based dengan PLS. dengan pertimbangan (1) PLS merupakan metode analisis yang powerfull oleh karena tidak didasarkan banyak asumsi (2) Data tidak harus berdistribusi normal multivariate (3)Jumlah sampel yang diteliti tidak harus dalam jumlah besar, karena lebih menitikberatkan pada model prediksi sehingga dukungan teori yang kuat tidak begitu menjadi hal terpenting (4) PLS dapat menjelaskan ada atau tidaknya hubungan antar variabel laten (5) PLS dapat menganalisa sekaligus konstruk yang dibentuk dengan indikator refleksif dan indikator formatif (Wold, 1985; Ghozali, 2008: 4).

Proses analisa data hasil penelitian dilakukan dengan tahapan dan cara (1) Analisis Profil Responden,yaitu kuisioner yang dapat diolah dianalisis untuk melihat identitas Wajib Pajak yang menjadi responden (2) Deskripsi Variabel Penelitian, yaitu masing- masing variabel penelitian yang terdiri dari variabel eksogen dan endogen dianalisis untuk melihat kisaran teoritis dan aktual dengan melihat standar deviasinya (3) Analisis Data dan Evaluasi Model dengan Metode PLS dengan menggunakan software SmartPLS versi 2.0.

Adapun langkah-langkah yang dilakukan dalam menganalisa data dan mengevaluasi model dengan metode PLS adalah (1) Evaluasi model pengukuran (outer model), (2) Evaluasi model struktural (inner model), (3) Merancang diagram jalur, (4) Membuat sistem persamaan model.

\section{Pengujian Hipotesis}

Setelah analisis data selesai dan diketahui hasilnya, dilakukan pengujian hipotesis yang telah ditentukan sebelumnya, berdasarkan tujuan penelitian. Tingkat kepercayaan yang 


\section{TRANSPARANSI}

Jurnal Ilmiah Ilmu Administrasi

ISSN 2085-1162

digunakan adalah 95\%, sehingga tingkat presisi atau batas ketidakakuratan sebesar $(\alpha)$ $=5 \%=0,05$. Dan menghasilkan nilai t-tabel sebesar 1.973, sehingga:

a. Jika nilai t-statistik lebih kecil dari nilai t-tabel [t-statistik < 1.973],

b. Jika nilai t-statistik lebih besar atau sama dengan t-tabel [ $\mathrm{t}$-statistik > 1.973], maka Ho ditolak dan Ha diterima

Ada atau tidaknya pengaruh dari masingmasing variabel terhadap perilaku kepatuhan pajak dan berapa besar pengaruhnya dapat dilihat dari hasil pengolahan data. Kemudian peneliti menganalisis hasil dari pengolahan data dan pengujian hipotesis dengan teori yang ada dan fakta yang terjadi serta dikaitkan dengan penelitian sebelumnya.

\section{HASIL DAN PEMBAHASAN}

\section{Profil Responden}

Profil responden dikelompokkan berdasarkan usia, jenis kelamin, pendidikan terakhir dan aktivitas memperoleh penghasilan.

Berdasarkan usia, responden berusia antara 35-45 tahun adalah yang terbanyak sejumlah 60 responden atau 33,71\%, berdasarkan jenis kelamin, mayoritas responden adalah laki-laki sebanyak 113 responden atau $63,48 \%$, berdasarkan pendidikan responden terbanyak adalah sarjana lulusan S1 sebanyak 87 responden atau 48,88\%, berdasarkan aktivitas memperoleh penghasilan mayoritas sebagai pegawai yaitu sebanyak 139 responden atau $78,09 \%$.

\section{Analisis Data dan Evaluasi Model}

Langkah-langkah yang dilakukan dalam menganalisa data dan mengevaluasi model dengan metode PLS adalah sebagai berikut:

\section{Evaluasi model pengukuran (outer model)}

Evaluasi model pengukuran dilakukan dengan 3 (tiga) cara, sebagai berikut:

a. Convergent Validity

Convergent validity dapat dilihat dari hasil Uji terhadap outer loading. Indikator dianggap reliabel jika memiliki nilai korelasi diatas 0,7 namun dalam tahap pengembangan korelasi 0,5 sampai 0,6 masih dapat diterima (Ghozali, 2008: 24).

Tabel 4.1 Uji Outer Loading

\begin{tabular}{|c|c|c|c|c|}
\hline & $\begin{array}{c}\text { original } \\
\text { sample } \\
\text { estimate }\end{array}$ & $\begin{array}{c}\text { mean of } \\
\text { subsamples }\end{array}$ & $\begin{array}{l}\text { Standard } \\
\text { deviation }\end{array}$ & T-Statistic \\
\hline \multicolumn{5}{|l|}{$\begin{array}{l}\text { PENGETAHUAN } \\
\text { PAJAK }\end{array}$} \\
\hline PP1 & 0,856 & 0,855 & 0,047 & 18,160 \\
\hline PP2 & 0,761 & 0,767 & 0,056 & 13,686 \\
\hline PP3 & 0,847 & 0,841 & 0,054 & 15,819 \\
\hline PP4 & 0,807 & 0,806 & 0,049 & 16,445 \\
\hline PP5 & 0,831 & 0,824 & 0,052 & 16,066 \\
\hline PP6 & 0,726 & 0,725 & 0,062 & 11,808 \\
\hline \multicolumn{5}{|l|}{$\begin{array}{c}\text { SIKAP WAJIB } \\
\text { PAJAK }\end{array}$} \\
\hline SWP1 & 0,968 & 0,970 & 0,008 & 127,049 \\
\hline SWP2 & 0,991 & 0,991 & 0,008 & 131,782 \\
\hline WP3 & 0,947 & 0,948 & 0,018 & 54,029 \\
\hline \multicolumn{5}{|l|}{$\begin{array}{c}\text { PENGETAHUAN } \\
\text { ZAKAT } \\
\end{array}$} \\
\hline PZ1 & 0,841 & 0,831 & 0,047 & 18,079 \\
\hline
\end{tabular}


Muhammad Yusuf, Tubagus Ismail , Pengaruh Pengetahuan Pajak, Pengetahuan Zakat ...

\begin{tabular}{|c|c|c|c|c|}
\hline PZ2 & 0,822 & 0,819 & 0,051 & 16,180 \\
\hline PZ3 & 0,774 & 0,788 & 0,051 & 15,100 \\
\hline $\begin{array}{c}\text { KEPATUHAN } \\
\text { PAJAK }\end{array}$ & & & & \\
\hline KP1 & 0,854 & 0,854 & 0,044 & 19,277 \\
\hline KP2 & 0,878 & 0,877 & 0,034 & 25,813 \\
\hline KP3 & 0,883 & 0,880 & 0,040 & 21,831 \\
\hline
\end{tabular}

Sumber : Hasil Pengolahan Data Penelitian 2015

Dalam tabel 4.1 dapat dilihat bahwa hasil pengolahan dengan menggunakan Smart PLS nilai outer loading indikator seluruh variabel tidak terdapat nilai yang kurang dari 0,7. Hal ini menunjukan bahwa setiap indikator pada seluruh konstruk dianggap reliabel dan telah memenuhi convergent validity sehingga tidak diperlukan eliminasi.

b. Discriminant Validity

Metode untuk menilai Discriminant
Validity dari model pengukuran dengan refleksif indikator dinilai berdasarkan crossloading antara indikator dengan konstruknya. Jika korelasi konstruk dengan item pengukurannya lebih besar dari pada ukuran konstruk lainnya, maka menunjukkan bahwa konstruk laten memprediksi ukuran pada blok mereka lebih baik dari pada ukuran pada blok lainnya (Ghozali, 2008 :25).

Tabel 4.2 Uji Cross Loading

\begin{tabular}{|c|c|c|c|c|}
\hline & $\begin{array}{l}\text { Pengetahuan } \\
\text { Pajak }\end{array}$ & $\begin{array}{l}\text { Sikap Wajib } \\
\text { Pajak }\end{array}$ & $\begin{array}{l}\text { Pengetahuan } \\
\text { Zakat }\end{array}$ & $\begin{array}{l}\text { Kepatuhan } \\
\text { Pajak }\end{array}$ \\
\hline PP1 & 0,856 & 0,359 & 0,302 & 0,421 \\
\hline PP2 & 0,761 & 0,300 & 0,297 & 0,301 \\
\hline PP3 & 0,847 & 0,404 & 0,411 & 0,334 \\
\hline PP4 & 0,807 & 0,346 & 0,274 & 0,463 \\
\hline PP5 & 0,831 & 0,425 & 0,403 & 0,352 \\
\hline PP6 & 0,726 & 0,300 & 0,366 & 0,286 \\
\hline SWP1 & 0,439 & 0,968 & 0,479 & 0,462 \\
\hline SWP2 & 0,442 & 0,991 & 0,457 & 0,447 \\
\hline SWP3 & 0,411 & 0,947 & 0,434 & 0,374 \\
\hline PZ1 & 0,373 & 0,435 & 0,841 & 0,335 \\
\hline PZ2 & 0,354 & 0,349 & 0,822 & 0,333 \\
\hline PZ3 & 0,300 & 0,362 & 0,774 & 0,338 \\
\hline KP1 & 0,382 & 0,338 & 0,387 & 0,854 \\
\hline KP2 & 0,457 & 0,360 & 0,280 & 0,878 \\
\hline KP3 & 0,345 & 0,457 & 0,409 & 0,883 \\
\hline
\end{tabular}

Sumber : Hasil Pengolahan Data Penelitian 2015

Berdasarkan hasil pengolahan data nilai crossloading pada tabel 4.2 dapat terlihat bahwa korelasi konstruk sikap dengan indikatornya lebih tinggi dibandingkan korelasi indikator lainnya, yaitu pengetahuan pajak, pengetahuan zakat dan kepatuhan pajak. Begitu juga seterusnya setiap blok indikator memiliki loading yang lebih tinggi untuk setiap variabel laten yang diukur dibandingkan dengan indikator variabel laten lainnya, hal ini menunjukkan bahwa konstruk laten memprediksi ukuran pada blok mereka lebih baik dari pada ukuran pada blok lainnya.

Metode lain untuk menilai Discriminant Validity adalah dengan membandingkan akar kuadrat dari average variance extracted masing-masing konstruk ( $\sqrt{ }$ AVE). Model mempunyai disciminant validity yang cukup 
jika akar AVE untuk setiap konstruk lebih besar dari pada korelasi antara konstruk dan konstruk lainnya dalam model, selain itu dipersyaratkan model yang baik apabila AVE masing-masing konstruk nilainya lebih besar dari 0,50. (Ghozali, 2008: 42)

Tabel 4.3 AVE dan Indeks Korelasi

\begin{tabular}{|c|c|c|c|c|c|c|}
\hline \multirow{2}{*}{ Variabel } & \multicolumn{2}{|c|}{$\begin{array}{c}\text { Average } \\
\text { Variance } \\
\text { Extracted }\end{array}$} & \multicolumn{4}{|c|}{ Index Correlations } \\
\cline { 2 - 7 } & AVE & $\begin{array}{c}\sqrt{\text { AVE }} \\
\text { AVengetahua } \\
\text { n Pajak }\end{array}$ & $\begin{array}{c}\text { Sikap } \\
\text { Wajib } \\
\text { Pajak }\end{array}$ & $\begin{array}{c}\text { Pengetahua } \\
\text { n Zakat }\end{array}$ & $\begin{array}{c}\text { Kepatuhan } \\
\text { Pajak }\end{array}$ \\
\hline Pengetahuan Pajak & 0,6498 & 0,806 & 1,000 & 0,000 & 0,000 & 0,452 \\
\hline Sikap Wajib Pajak & 0,9388 & 0,969 & 0,444 & 1,000 & 0,472 & 0,444 \\
\hline Pengetahuan Zakat & 0,6607 & 0,813 & 0,422 & 0,000 & 1,000 & 0,412 \\
\hline Kepatuhan Pajak & 0,7598 & 0,872 & 0,000 & 0,000 & 0,000 & 1,000 \\
\hline
\end{tabular}

Sumber : Hasil Pengolahan Data Penelitian 2015

Tabel 4.3 di atas menjelaskan nilai dari AVE dan akar AVE dari variabel konstruk pengetahuan pajak, sikap, pengetahuan zakat dan kepatuhan Pajak.

Berdasarkan tabel tersebut dapat dilihat bahwa nilai akar AVE setiap konstruk lebih besar dari nilai korelasi antar konstruk dengan konstruk lainnya, sebagai berikut:

1) Nilai akar AVE konstruk pengetahuan pajak, nilai akar AVE konstruk pengetahuan pajak sebesar 0,806 lebih tinggi dari pada nilai korelasi antara pengetahuan pajak dengan sikap sebesar 0,444 , nilai korelasi antara antara pengetahuan pajak dengan pengetahuan zakat sebesar 0,422, maupun dengan nilai korelasi pengetahuan pajak dengan kepatuhan pajak sebesar 0,452 .

2) Nilai akar AVE konstruk sikap wajib pajak, nilai akar AVE konstruk sikap sebesar 0,969 lebih tinggi dari pada nilai korelasi antara sikap dengan pengetahuan pajak sebesar 0,444, nilai korelasi antara sikap dengan pengetahuan zakat sebesar 0,472 , maupun dengan nilai korelasi antara sikap dengan kepatuhan pajak sebesar 0,444 .

3) Nilai akar AVE konstruk pengetahuan
4) pengetahuan zakat sebesar 0,813 lebih tinggi dari pada nilai korelasi antara pengetahuan zakat dengan pengetahuan pajak sebesar 0,422, nilai korelasi antara pengetahuan zakat dengan sikap sebesar 0,472, maupun nilai korelasi antara pengetahuan zakat dengan kepatuhan pajak sebesar 0,412 .

5) Nilai akar AVE konstruk kepatuhan pajak Nilai akar AVE konstruk kepatuhan pajak sebesar 0,872 lebih tinggi dari pada nilai korelasi antara kepatuhan pajak dengan pengetahuan pajak sebesar 0,452 , nilai korelasi antara kepatuhan pajak dengan sikap sebesar 0,444 maupun dengan nilai korelasi antara kepatuhan pajak dengan pengetahuan zakat sebesar 0,412 .

Selain itu tabel diatas menunjukan juga bahwa setiap konstruk (variabel) tersebut memiliki nilai AVE diatas 0,5. Hal ini menunjukkan bahwa setiap konstruk tersebut memiliki nilai validitas yang baik dari setiap indikatornya atau kuesioner yang digunakan untuk mengetahui pengaruh pengetahuan pajak, sikap, pengetahuan zakat dan kepatuhan pajak dapat dikatakan valid.

Selain itu tabel diatas menunjukan juga bahwa setiap konstruk (variabel) 
Muhammad Yusuf, Tubagus Ismail , Pengaruh Pengetahuan Pajak, Pengetahuan Zakat ...

tersebut memiliki nilai AVE diatas 0,5. Hal ini menunjukkan bahwa setiap konstruk tersebut memiliki nilai validitas yang baik dari setiap indikatornya atau kuesioner yang digunakan untuk mengetahui pengaruh pengetahuan pajak, sikap, pengetahuan zakat dan kepatuhan pajak dapat dikatakan valid.

c. Composite Reliability

Composite reliability untuk mengukur internal consistency, Suatu data dikatakan reliabel jika composite reliability lebih dari 0,7. dari tabel 4.4 dapat dilihat setiap konstruk atau variabel laten tersebut memiliki nilai composite reliability diatas 0,7 yang menandakan bahwa internal consistency antar variabel memiliki reliabilitas yang baik.

Tabel 4.4 Composite Reliability

\begin{tabular}{|c|c|}
\hline Variabel & $\begin{array}{c}\text { Composite } \\
\text { Reliability }\end{array}$ \\
\hline Pengetahuan Pajak & 0,9173 \\
\hline Sikap & 0,9787 \\
\hline Pengetahuan Zakat & 0,8537 \\
\hline Kepatuhan Pajak & 0,9047 \\
\hline
\end{tabular}

Sumber : Hasil Pengolahan Data Penelitian 2015

Evaluasi model struktural (inner model)

Evaluasi model struktural (inner model) dilakukan dengan menggunakan 2 (dua) cara pengujian, yaitu :

\section{d. Uji R-Square}

Dalam menilai struktural model PLS dapat dilihat berdasarkan nilai R-Square untuk setiap variable latennya yang merupakan uji goodness-fit model.

Tabel 4.5 R-Square

\begin{tabular}{|c|c|}
\hline Variabel & R-Square \\
\hline Pengetahuan Pajak & 0,000 \\
\hline Sikap & 0,296 \\
\hline Pengetahuan Zakat & 0,000 \\
\hline Kepatuhan Pajak & 0,303 \\
\hline
\end{tabular}

Sumber : Hasil Pengolahan Data Penelitian 2015

Tabel 4.5 menunjukkan nilai R-square konstruk sikap sebesar 0,296 dan konstruk
Kepatuhan Pajak sebesar 0,303. Semakin tinggi R-square, maka semakin besar variabel independen tersebut dapat menjelaskan variabel dependen sehingga semakin baik persamaan struktural. Untuk variabel sikap memiliki nilai R-square sebesar 0,296 yang berarti bahwa variabilitas konstruk sikap yang dapat dijelaskan oleh variabilitas pengetahuan pajak dan pengetahuan zakat sebesar 29,6\% sedangkan sisanya $70,4 \%$ dijelaskan oleh variabel lain diluar yang diteliti dalam penelitian ini, sedangkan variabel kepatuhan pajak memiliki nilai R-square sebesar 0,303 yang berarti bahwa variabilitas konstruk kepatuhan pajak yang dapat dijelaskan oleh variabilitas pengetahuan pajak, pengetahuan zakat dan sikap sebesar $30,3 \%$ sedangkan sisanya $69,7 \%$ dijelaskan oleh variabel lain diluar yang diteliti dalam penelitian ini.

Kriteria batasan nilai $\mathrm{R}^{2}$ endogen dalam model struktural dibagi dalam tiga klasifikasi, yaitu $0,67,0,33$, dan 0,19 yang mengindikasikan bahwa model "Baik", "Moderat" dan "Lemah" (Ghozali, 2008 : 27), sehingga dapat dinyatakan bahwa pengaruh pengetahuan pajak, pengetahuan zakat dan sikap terhadap kepatuhan pajak adalah baik, sedangkan pengaruh pengetahuan pajak dan pengetahuan zakat terhadap sikap termasuk dalam kategori moderat.

e. Uji Q-Square

Disamping melihat nilai R-square, untuk mengukur model konstruk digunakan Q-square predictive relevance. Q-square dapat mengukur seberapa baik nilai observasi yang dihasilkan oleh model dan juga estimasi parameternya. Nilai Q-square lebih besar dari 0 (nol) menunjukan bahwa model mempunyai nilai predictive relevance, sedangkan nilai Qsquare kurang dari 0 (nol) menunjukan bahwa model kurang memiliki predictive relevance (Ghozali, 2008 : 26). Perhitungan Q-Square dapat dapat dilakukan dengan rumus :

$\mathrm{Q} 2$ = 1- (1 - R12) $(1-\mathrm{R} 22)$.... (1 - Rp2)

Di mana R12, R22... Rp2 adalah R-square variabel endogen dalam model.

Mengacu pada nilai $\mathrm{R}$ square yang ada pada tabel 5.13 diatas, dapatdiketahui nilai Q2 dengan menggunakan rumus Stone-Geisser Q square test sebagai berikut : 


\section{TRANSPARANSI}

Jurnal Ilmiah Ilmu Administrasi

ISSN 2085-1162

$$
\begin{aligned}
& \mathrm{Q} 2=1-(1-\mathrm{R} 12)(1-\mathrm{R} 22) \\
& \mathrm{Q} 2=1-(1-0,296)(1-0,303) \\
& \mathrm{Q} 2=0,5093 \text { atau } 50,93 \%
\end{aligned}
$$

Berdasarkan hasil perhitungan dengan menggunakan rumus diatas, diketahui bahwa nilai Q2 sebesar 50,93\%, artinya model yang digunakan dalam penelitian ini dapat menjelaskan informasi yang terkandung dalam data penelitian sebesar 50,93\% .

\section{Merancang diagram jalur}

output smart PLS seperti pada gambar 4.1

Gambar 4.1 Full Structural Model

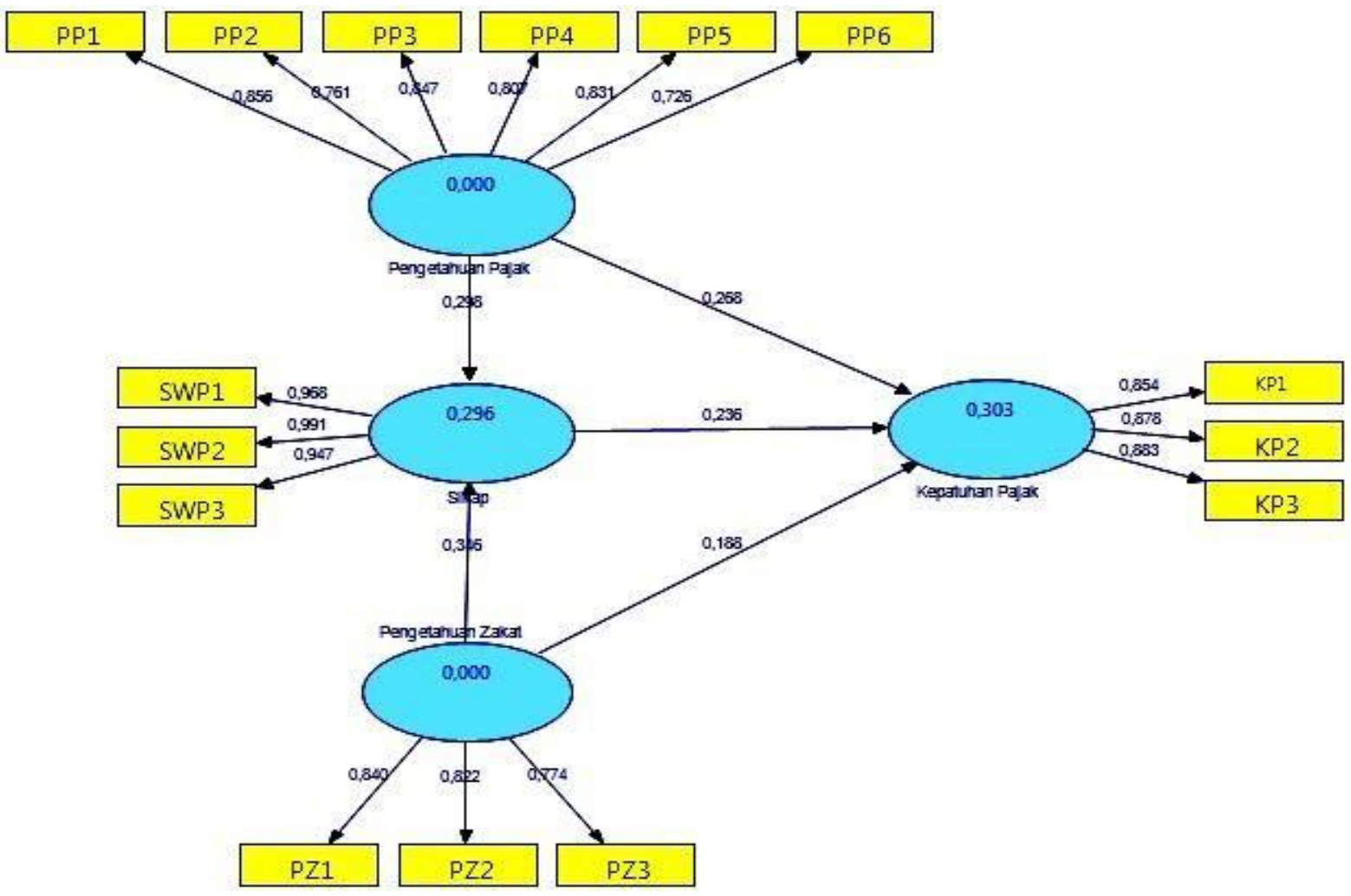

Membuat sistem persamaan model

Tabel 4.6 Hasil Inner Weights

\begin{tabular}{|c|r|r|r|c|}
\hline & $\begin{array}{c}\text { Original } \\
\text { Sample }\end{array}$ & $\begin{array}{c}\text { Sample } \\
\text { Mean }\end{array}$ & $\begin{array}{c}\text { Standard } \\
\text { Deviation }\end{array}$ & $\begin{array}{c}\text { T - } \\
\text { Statistics }\end{array}$ \\
\hline Pengetahuan Pajak -> Kepatuhan Pajak & 0,338 & 0,334 & 0,092 & 3,678 \\
\hline Pengetahuan Pajak -> Sikap & 0,298 & 0,308 & 0,080 & 3,719 \\
\hline $\begin{array}{c}\text { Pengetahuan Zakat -> Sikap } \\
\text { Pengetahuan Zakat -> Kepatuhan } \\
\text { Pajak }\end{array}$ & 0,346 & 0,345 & 0,079 & 4,363 \\
\hline
\end{tabular}


Muhammad Yusuf, Tubagus Ismail , Pengaruh Pengetahuan Pajak, Pengetahuan Zakat ...

\begin{tabular}{|c|r|r|r|r|}
\hline Sikap -> Kepatuhan Pajak & 0,236 & 0,219 & 0,103 & 2,296 \\
\hline
\end{tabular}

Sumber : Hasil Pengolahan Data Penelitian 2015

Berdasarkan hasil inner weight pada tabel 5.14 diatas dapat dibuat persamaan inner model penelitian ini, sebagai berikut:

$$
\begin{aligned}
& \eta 1=0,338 \beta 1+0,270 \beta 2+0,236 \beta 3+\Gamma \xi \\
& +\zeta \text { dan } \eta 2=0,298 \beta 1+0,346 \beta 2+\Gamma \xi+ \\
& \zeta
\end{aligned}
$$

Dimana:

$\eta 1$ : Kepatuhan Pajak

$\eta 2$ : Kepatuhan Zakat $\beta 1$ : Pengetahuan Pajak $\beta 2$ : Pengetahuan Zakat $\beta 3$ :

Sikap

$\xi$ : Vektor variabel laten exogen, dan

$\zeta$ : Vektor variabel residual

Sedangkan untuk persamaan

outer model untuk masing-masing variabel eksogen dan variabel endogen dalam penelitian ini adalah sebagai berikut:

1) Variabel Pengetahuan Pajak (PP), adalah: $\mathrm{x}_{1}=0,856 \mathrm{x}_{1} \xi_{1}+\varepsilon \mathrm{x}_{1}$ $\mathrm{x}_{2}=0,761 \mathrm{x}_{2} \xi_{1}+\varepsilon \mathrm{x}_{2} \mathrm{x}_{3}=0,847 \mathrm{x}_{3}$ $\xi_{1}+\varepsilon x_{3} x_{4}=0,807 x_{4} \xi_{1}+\varepsilon x_{4} x_{5}=$ $0,831 \mathrm{x}_{5} \xi_{1}+\varepsilon \mathrm{x}_{5} \mathrm{x}_{6}=0,726 \mathrm{x}_{6} \xi_{1}+$ Ex 6

2) Variabel Pengetahuan Zakat (PZ), adalah: $\mathrm{x}_{7}=0,840 \mathrm{x}_{7} \xi_{2}+\varepsilon \mathrm{x}_{7}$ $\mathrm{x}_{8}=0,822 \mathrm{x}_{8} \xi_{2}+\varepsilon \mathrm{x}_{8}$ $\mathrm{x}_{9}=0,774 \mathrm{x}_{9} \xi_{2}+\varepsilon \mathrm{x}_{9}$

3) Variabel Sikap Wajib Pajak (SWP) adalah $\mathrm{y}_{1}=0,968 \mathrm{y}_{1} \eta_{1}+\varepsilon \mathrm{y}_{1}$ $\mathrm{y}_{2}=0,991 \mathrm{y}_{2} \eta_{1}+\varepsilon \mathrm{y}_{2}$ $\mathrm{y}_{3}=0,947 \mathrm{y}_{3} \eta_{1}+\varepsilon \mathrm{y}_{3}$

4) Variabel Kepatuhan Pajak (KP), adalah: $\mathrm{y}_{4}=0,854 \mathrm{y}_{1} \eta_{1}+\varepsilon \mathrm{y}_{1}$

$\mathrm{y}_{5}=0,878 \mathrm{y}_{2} \eta_{1}+\varepsilon \mathrm{y}_{2}$ $\mathrm{y}_{6}=0,883 \mathrm{y}_{3} \eta_{1}+\varepsilon \mathrm{y}_{3}$

Dimana:

$\mathrm{x}_{1}$ : indikator fungsi NPWP

$\mathrm{x}_{2}$ : indikator pengetahuan hak dan kewajiban wajib pajak $\mathrm{x}_{3}$ : indikator pengetahuan sanksi perpajakan $\mathrm{X}_{4}$ : indikator pengetahuan tentang PTKP,PKP dan tarif pajak $\mathrm{x}_{5}$ : indikator sosialisasi perpajakan $\mathrm{x}_{6}$ : indikator training/pelatihan perpajakan

$\mathrm{x}_{7}$ : indikator pengetahuan zakat merupakan kewajiban muslim $\mathrm{x}_{8}$ : indikator pengetahuan penghasilan merupakan objek zakat $\mathrm{x}_{9}$ : indikator pengetahuan mengenai fungsi zakat $\mathrm{y}_{1}$ : indikator sikap keinginan membayar pajak lebih kecil $\mathrm{y}_{2}$ : indikator sikap merasa tidak dirugikan oleh sistem perpajakan $y_{3}$ : indikator pemanfaatan pajak yang sudah transparan

$\mathrm{y}_{4}$ : indikator penyetoran pajak $\mathrm{y}_{5}$ : indikator penyerahan/penyampaian SPT y $_{5}$ : indikator pelaporan pajak $\xi_{1}$ : variabel pengetahuan pajak $\xi_{2}$ : variabel pengetahuan zakat

$\eta_{1}$ : variabel sikap

$\eta_{2}$ : variabel kepatuhan pajak

\section{Pengujian Hipotesis}

Hasil inner weight di atas dapat menjawab hipotesis yang sudah ditentukan sebelumnya :

1. Hipotesis 1, Pengetahuan pajak berpengaruh terhadap kepatuhan pajak. Dengan nilai original sampel estimate sebesar 0,338 dan t-hitung sebesar 3,678 (lebih besar dari t-tabel 1.973) menyatakan bahwa Pengetahuan pajak secara signifikan berpengaruh terhadap terhadap kepatuhan pajak.

2. Hipotesis 2, Pengetahuan zakat berpengaruh terhadap kepatuhan pajak.

Dengan nilai original sampel estimate sebesar 0,270 dan t-hitung sebesar 2,174 (lebih besar dari t-tabel 1.973) menyatakan bahwa pengetahuan zakat secara signifikan berpengaruh terhadap terhadap kepatuhan pajak.

3. Hipotesis 3, Pengetahuan pajak berpengaruh terhadap sikap.

Dengan nilai original estimate sebesar 0,298 dan t-hitung sebesar 3,719 (lebih besar dari t-tabel 1.973) menjelaskan bahwa pengetahuan pajak berpengaruh terhadap sikap wajib pajak. 


\section{TRANSPARANSI}

Jurnal Ilmiah Ilmu Administrasi

ISSN 2085-1162

4. Hipotesis 4, Pengetahuan zakat

berpengaruh terhadap sikap.

Dengan nilai original sampel estimate sebesar 0,346 dan t-statistik sebesar 4,363

(lebih besar dari t-tabel 1.973) menjelaskan bahwa pengetahuan zakat secara signifikan berpengaruh langsung terhadap sikap wajib pajak.

5. Hipotesis 5, Sikap berpengaruh terhadap kepatuhan pajak.

Dengan nilai original sampel estimate sebesar 0,236 dan t-statistik sebesar 2,296

(lebih besar dari t-tabel 1.973) menjelaskan bahwa sikap secara signifikan tidak berpengaruh secara signifikan terhadap kepatuhan pajak.

Selain itu hasil inner weight di atas menjelaskan bahwa pengetahuan pajak dan pengetahuan zakat berpengaruh langsung terhadap kepatuhan wajib pajak, tetapi juga berpengaruh tidak langsung terhadap kepatuhan wajib pajak melalui sikap. Pengaruh pengetahuan pajak dan pengetahuan zakat terhadap kepatuhan wajib pajak baik langsung maupun tidak langsung dapat dihitung berdasarkan hasil inner weight sebagai berikut:

\begin{tabular}{|lll|}
\hline Pengaruh langsung & $: \mathrm{PP}$ & $\longrightarrow \mathrm{KP}=0,338$ \\
Pengaruh tidak langsung & $: \mathrm{PP}$ & $\longrightarrow \mathrm{KP}=0,070$ \\
$(0,298) \times(0,236)=0,070$ & & \\
$\begin{array}{l}\text { Pengaruh langsung } \\
\text { Pengaruh tidak langsung }\end{array}$ & $: \mathrm{PZ}$ & $\longrightarrow \mathrm{KP}=0,270$ \\
$(0,346) \mathrm{x}(0,236)=0,082$ & & $\longrightarrow \mathrm{KP}=0,082$ \\
\hline
\end{tabular}

Hal ini menunjukan bahwa koefisien pengaruh langsung lebih besar dari pada pengaruh tidak langsung.

\section{Pembahasan}

Hasil pengujian atas variabel pengetahuan pajak berpengaruh secara signifikan terhadap kepatuhan pajak. Hasil penelitian ini konsisten dengan penelitian Witono (2008) yang menyebutkan bahwa semakin baik pengetahuan wajib pajak terhadap peraturan pajak maka semakin tinggi tingkat kepatuhan wajib pajak dan pengetahuan pajak dan keadilan sistem pajak baik bersama-sama maupun sendiri-sendiri berpengaruh yang signifikan terhadap kepatuhan wajib pajak.

Pengetahuan tentang peraturan peraturan perpajakan penting untuk menumbuhkan perilaku patuh, sebab Wajib Pajak tidak akan mungkin patuh apabila mereka tidak mengetahui peraturan perpajakan, kapan dia harus membayar, kapan harus melapor bagaimana cara menghitung pajak yang sesuai dengan ketentuan perpajakan (Witono, 2008). Pengetahuan tentang pajak dapat diperoleh wajib pajak dari petugas pajak, televisi, internet, surat kabar, buku perpajakan, seminar dan pelatihan perpajakan. Bertambahnya wawasan wajib pajak mampu memberikan kesadaran akan pentingnya pajak bagi mereka, masyarakat dan negara.

Hasil penelitian atas variabel Pengetahuan zakat berpengaruh terhadap kepatuhan pajak. Seperti yang diungkapkan oleh Buchori bahwa Faktor pendidikan, agama, kesadaran, Undang-undang dan peraturan serta faktor lingkungan dan sikap fiskus mempengaruhi kepatuhan wajib pajak, tetapi wajib pajak tidak patuh dalam implementasi zakat sebagai pengurang pajak terutangnya di SPT. Pengetahuan mengenai zakat, seperti regulasi pemerintah mengenai perpajakan dan zakat tercantum di UU Nomor 38 Tahun 1999 mengenai zakat sebagai pengurang penghasilan kena pajak, dapat mempengaruhi kepatuhan pajak. setiap wajib pajak muslim akan dapat memanfaatkan peraturan tersebut untuk mengurangi jumlah penghasilan kena pajak dalam pelaporan pajaknya. Fitranoska (2006) dalam penelitiannya ditemukan hubungan positif yang kuat antara Zakat sebagai pengurang 
Muhammad Yusuf, Tubagus Ismail , Pengaruh Pengetahuan Pajak, Pengetahuan Zakat ...

Penghasilan Kena Pajak dengan pemenuhan kewajiban pajak.

Pengetahuan wajib pajak mengenai adanya sinergi peraturan pajak antara Undang-undang Nomor 38 tahun 1999 tentang pengelolaan zakat dengan Undangundang Nomor 17 tahun 2000 tentang pajak penghasilan, dengan mengakui zakat sebagai pengurang penghasilan kena pajak mempengaruhi sikap wajib pajak untuk melaksanakan kepatuhan pajak dengan menjadikan zakat sebagai pengurang penghasilan kena pajak. Dengan demikian, hal ini sesuai dengan hasil penelitian yang telah dilakukan bahwa pengetahuan pajak dan pengetahuan zakat berpengaruh terhadap sikap wajib pajak.

Sejalan dengan penelitian, Fallan (1999) menyatakan bahwa aspek pengetahuan perpajakan bagi wajib pajak sangat mempengaruhi sikap wajib Pajak, begitu pun dengan penelitian yang dilakukan oleh Idris \& Ayob (2011) menyatakan bahwa sikap muzakki dipengaruhi diantaranya oleh pengetahuan. Hal ini dikarenakan pengaruh tingkat pemahaman (pengetahuan) dan kesadaran wajib pajak tersebut terhadap implikasi positif atas sinergi kebijakan peraturan zakat dan pajak tersebut.

Peningkatan pengetahuan perpajakan memiliki signifikansi terhadap perubahan sikap wajib pajak. Muarifah (2013) dalam penelitiannya menyimpulkan bahwa sikap wajib pajak berpengaruh positif terhadap kepatuhan wajib pajak. Dengan meningkatnya kualitas pengetahuan yang semakin baik melalui melalui pendidikan perpajakan baik formal maupun nonformal akan berdampak positif terhadap pemahaman dan kesadaran Wajib Pajak dalam melaksanakan kepatuhan pajak.

\section{SIMPULAN, IMPLIKASI DAN SARAN}

\section{Simpulan}

Berdasarkan hasil pembahasan pada bab sebelumnya, dapat disusun beberapa kesimpulan hasil penelitian ini, sebagai berikut:

1. Pengetahuan Pajak berpengaruh secara signifikan terhadap kepatuhan wajib pajak. Hasil ini menunjukan bahwa pengetahuan tentang perpajakan penting untuk menumbuhkan perilaku patuh karena dengan bertambahnya wawasan tentang perpajakan wajib pajak mampu memberikan kesadaran akan pentingnya pajak bagi mereka, masyarakat dan negara. Pengetahuan dan tentang peraturan perpajakan akan meningkatkan kemauan wajib pajak untuk membayar pajak, karena wajib pajak yang memiliki pengetahuan peraturan perpajakan berpikir lebih baik membayar daripada terkena sanksi. Disamping itu tanpa pengetahuan pajak wajib pajak tidak akan mungkin patuh karena mereka tidak mengetahui peraturan perpajakan, bagaimana perhitungan pajak terutang, kapan dan dimana harus membayar pajak, kapan dan dimana harus melapor pajak agar sesuai dengan ketentuan perpajakan.

2. Pengetahuan zakat berpengaruh terhadap kepatuhan pajak. Pengetahuan zakat mengenai regulasi pemerintah Undangundanh Nomor 38 Tahun 1999 mengenai zakat sebagai pengurang penghasilan kena pajak dapat mempengaruhi kepatuhan pajak. Setiap wajib pajak muslim dengan pengetahuannya akan dapat memanfaatkan peraturan tersebut untuk mengurangi jumlah penghasilan kena pajak dalam pelaporan pajaknya.

3. Sikap Wajib Pajak mempengaruhi kepatuhan wajib pajak. Sikap wajib pajak terhadap peraturan sistem perpajakan dapat mempengaruhi bagaimana wajib pajak dalam memenuhi kewajiban perpajakannya. Pemanfaatan peraturan dan system perpajakan yang transparan memotivasi wajib pajak dalam melaksanakan kepatuhan pajaknya.

4. Pengetahuan pajak dan pengetahuan zakat mempengaruhi sikap wajib pajak. Pengetahuan Wajib Pajak Muslim tentang peraturan perpajakan seperti yang tercantum dalam UU No. 17 Tahun 2000 juga bisa mempengaruhi sikap mereka. Semakin tinggi pengetahuan terhadap regulasi pemerintah tersebut semakin memengaruhi keputusan wajib pajak untuk membayar zakat. Hal ini picu 


\section{TRANSPARANSI}

Jurnal Ilmiah Ilmu Administrasi

ISSN 2085-1162

karena memotivasi wajib pajak muslim untuk membayarkan zakat dan menjadikan zakat sebagai pengurang penghasilan kena pajak. Dengan kualitas pengetahuan yang semakin baik, wajib pajak akan memberikan sikap menjalankan kepatuhan pajak sesuai dengan peraturan negara yang dianggap adil.

\section{Implikasi Kebijakan}

Hasil penelitian ini diharapkan dapat memberi masukan kepada pemerintah dalam hal ini adalah Direktorat Jendral Pajak dan Badan Amil Zakat untuk melakukan sosialisasi dan publikasi keberadaan UU tentang Pengelolaan Zakat No 38 Tahun 1999 dan atau UU No. 23 Tahun 2011 serta UU No 17 Tahun 2000 tentang Pajak Penghasilan. Terkait antara pajak dan zakat menjadi penting dilakukan oleh pemerintah, sebab hal ini dapat menjadi motivasi berpengaruh terhadap sikap wajib pajak untuk merealisasikan kedua UU tersebut.

Pelaksanaan regulasi tersebut dapat meningkatkan kepatuhan pajak dengan wujud implementasi zakat sebagai pengurang penghasilan kena pajak di Surat Pemberitahuan (SPT) saat pelaporan pajak.

Ketentuan perpajakan dan zakat yang jelas, pelaksanaan hingga sosialisasi diharapkan dapat membentuk hukum tak tertulis di masyarakat yang akan mempengaruhi wajib pajak muslim untuk patuh dalam melaksanakan kewajiban perpajakan dan zakatnya.

\section{Keterbatasan Penelitian}

Penelitian ini belum sempurna dan tidak terlepas dari keterbatasan dan kelemahan. Oleh karena itu keterbatasan dan kelemahan dalam penelitian ini diharapkan dapat menjadi masukan bagi penelitian selanjutnya. Adapun keterbatasan yang ditemukan dalam penelitian ini adalah:

1. Pemilihan populasi yang kurang spesifik, karena yang menjadi populasi adalah Wajib Pajak Orang pribadi yang memiliki penghasilan dan berpotensi membayarkan pajak dan zakatnya. Beberapa wajib pajaknya adalah wajib pajak yang mendapatkan penghasilan dari bekerja, sehingga kewajiban pajaknya telah melalui pemotongan penghasilan dari tempatnya bekerja. Tetapi tidak demikian dengan kewajiban zakatnya yang harus dibayarkan karena kesadaran sendiri.

2. Pencarian responden untuk dijadikan sampel pada penelitian ini adalah Wajib Pajak yang sedang melakukan pelaporan SPT di KPP, hal ini mungkin akan lebih baik jika pengisian kuisioner dilakukan di lokasi tempat umum, sehingga wajib pajak bisa dengan leluasa dan lebih fokus dalam mengisi kuisioner.

\section{Saran Penelitian Mendatang}

Hasil penelitian ini dengan segala keterbatasan dan kelemahan yang ada dapat dijadikan bahan masukan dan ide dasar bagi pengembangan penelitian di masa mendatang, maka dalam penelitian ini disarankan untuk melakukan pengumpulan data dengan cara yang lebih baik agar hasil data yang didapat dari kuisioner atau wawancara dapat lebih valid sesuai hati responden tanpa terganggu dengan keadaan saat pengisian kuisioner atau wawancara dilakukan. Penelitian selanjutnya juga diharapkan untuk meneliti tingkat kepatuhan zakat atas pengaruh pengetahuan wajib pajak mengenai adanya sinergi peraturan perpajakan dan zakat.

Selain itu diharapkan juga untuk lebih spesifik dalam pemilihan populasi yaitu seperti Wajib Pajak Orang Pribadi Muslim yang melakukan kegiatan usaha dan pekerjaan bebas, memiliki klasifikasi usaha dan profesi. Dengan demikian diharapkan model penelitian nantinya dapat dikembangkan sebagai bahan masukan Direktorat Jenderal Pajak dan Badan Amil Zakat dalam meningkatkan tingkat kepatuhan pajak dan kepatuhan zakat sehingga penerimaan negara dari sektor pajak dan zakat dapat terus meningkat dari tahun ke tahun. 
Muhammad Yusuf, Tubagus Ismail , Pengaruh Pengetahuan Pajak, Pengetahuan Zakat ...

\section{DAFTAR PUSTAKA}

Ajzen, Icek (2006), Organizational Behavior and Human Decision Process, Academic Press. Inc.

Bakar, Abu. (2010). Motivations of Paying Zakat on Income. International Journal of Economics and Finance.

Buchori, Imam. (2010). Analisis FaktorFaktor Yang Mempengaruhi Tingkat Kepatuhan Wajib Pajak Muslim. Laporan Penelitian LEMLIT IAIN Sunan Ampel.

Buku Panduan Zakat PKPU (Pos Keadilan Peduli Umat).

Daud, Z., Ahmad, S., Fuad, A. R. (2011). Model Prilaku Kepatuhan Zakat: Suatu Pendekatan Teori. Jurnal Iqtishoduna Vol 7. No. 1.

Dayakisni, T. \& Hudaniah. (2003).

Psikologi Sosial. Malang:

Universitas Muhammadiyah.

Dewan Syariah LAZIS Muhammadiyah. (2004). Pedoman Zakat Praktis, Suara Muhammadiyah, Yogyakarta.

Doa, M Djamal. (2001) Membangun Ekonomi Umat: Melalui Pengelolaan Zakat Harta.

Jakarta: Nuansa Madani.

Fallan, Lars. 1999. Gender, Exposure to Tax Knowledge, and Attitudes Tiwards taxation, Aan Experimental Approach, Journal of Business Ethics, 18: p. 173184.

Fitranoska. (2006). Pengaruh zakat sebagai pengurang penghasilan kena pajak terhadap kepatuhan wajib Pajak Orang Pribadi: Pada KPP Pratama Jakarta Tanah Abang

III. Tesisi UI

Franzoni, A. Luigi. (1999). Tax Evasion and Tax Compliance. Italy: University of Bologna.

Gerungan. (2004). Psikologi Sosial. Bandung: Refika Aditama.

Ghazali, Ahmad. (2009). Kesan Tahap Keagamaan dan Akuntabiliti Peribadi Terhadap Niat Membayar Zakat Perniagaan di Kalangan Kontraktor Perniagaan Tunggal Pulau Pinang. Disertasi Sarjana Sastera, Universiti Sains Malaysia.
Ghozali, Imam. (2008) Structural Equations Modeling-Metode Alternatif dengan Partial Least Square (2nd ed). Semarang: Universitas Diponegoro

Gusfahmi. (2007). Pajak Menurut Syariah. Jakarta: PT RajaGrafindo Persada. Hadi Purnomo. (2004). Reformasi Administrasi Perpajakan. Jakarta: Kompas Hafidhuddin, D. (2002). Zakat Dalam Perekonomian Modern. Depok: Gema Insani

Hamidiyah, E. (2007). Zakat tak akan kurangi pajak. Diakses 2 Juli 2007, dari www.Republika.co.id.

Hidayati, Nur. (2010). Pengaruh Pengetahuan Pajak dan Kesadaran Wajib Pajak Terhadap Kepatuhan Pajak. Jurnal Akuntansi. Vol 4 No 1. Maret 2010. http://pusat.baznas.go.id/beritaartikel/zakat-sebagai-pengurangpenghasilan-kena-pajak/

http://www.ekon.go.id

Idris, Kamil., \& Ayob Ahmad., (2001). Attitude Toward Zakah On Employment Income: Comparing Outcomes Between Single Score And Multidimensional Score. Malaysian Manajement Journal 5 (1\&2), 47 - 63.

Ijma. (2014). Analisis Faktor-Faktor Yang Mempengaruhi Pembayaran Zakat Profesi Bagi PNS Muslim Pemda Kabupaten Tolitoli. Fakultas Ekonomi dan Bisnis, Universitas Negeri Gorontalo.

Jackson, B.R dan Milliron. V.C. (1986). Tax Compliance Research: Findings, Problem And Prospects. Journal of Accounting Literature,5. 125-165.

Jahrotunasipah, Ipah. (2012). Faktor-faktor Yang Mempengaruhi Keputusan Pegawai Negeri Sipil (PNS) Dilingkungan Pemerintah Daerah Kota Cirebon Untuk Membayar Zakat Profesi Melalui BAZ / LAZ Dengan Cara Pemotongan Gaji, Jurnal EQUALITA (Cirebon, IAIN Syekhnurdjati)

James, Simon dan Alley.C. (1999). Tax Compliance, Self Assesment and Tax Administration. Journal of Finance and Management in Public Service Volume 2 Number 2: pp. 27-42 
TRANSPARANSI

Jurnal Ilmiah Ilmu Administrasi

ISSN 2085-1162

Jujun S. Sumantri. (1993). Filsafat Ilmu : Sebuah Pengantar Populer. Jakarta: Pustaka Sinar Harapan.

Kamil Md. Idris. (2002). Gelagat Kepatuhan Zakat Pendapatan di Kalangan Kakitangan Awam Persekutuan Negeri Kedah. Tesis Kedoktoran, Universiti Utara Malaysia.

Kamil, M.I. (2005). The role of intrinsic motivational factors on compliance behaviour of zakat on employment income, in Isu-isu Kontemporari Zakat di Malaysia. (1st ed.). Melaka: UiTM pp. 137-170.

Kanji, Lusiana. Dkk. Tanpa Tahun. Aktor Determinan Motivasi Membayar Zakat. (http://pasca.unhas.ac.id/jurnal/file/pdf).

Karsino. (2009). Peluang Kesediaan Karyawan untuk Dipungut Zakat Profesi dengan Metode Withholding dan Faktor-Faktor yang Mempengaruhinya (Penelitian Terhadap Karyawan Swasta Di Jakarta), Tesis Universitas Indonesia, Program

Pascasarjana, Program Studi Timur Tengah dan Islam, Kkhususan Ekonomi dan Keuangan Syari'ah

Mohd Ali, dkk. (2004). Kesadaran Membayar Zakat Pendapatan dikalangan Kaki Tangan Profesional Universitas Kebangsaan Malaysia. diakses dari http://www.jurnal zakat.org, diakses pada tanggal 3 januari 2011

Muarifah, Tanzilah (2014). Pengaruh Pengetahuan Pajak, Kualitas Pelayanan Petugas Pajak Dan Sikap Wajib Pajak Terhadap Kepatuhan Wajib Pajak. Tesis Universitas Dian Nuswantoro.

Muktiyanto dan Hendrian. (2008). Zakat sebagai pengurang pajak. Jurnal Organisasi dan Manajemen. Universitas Terbuka

Mustikasari, Elia. (2007). Kajian empiris tentang kepatuhan wajib pajak badan di Perusahaan industri pengolahan di surabaya. Simposium Nasional Akuntansi X. 1-42

Notoatmodjo, S. (2007). Pendidikan dan Perilaku Kesehatan. Jakarta : PT.
Volume 9, Nomor 02, September 2017

Rineka Cipta.

Nugroho, Adi Rahman \& Zulaikha. (2012). Faktor-faktor yang mempengaruhi kemauan untuk Membayar pajak dengan kesadaran membayar pajak Sebagai variabel intervening (Studi Kasus Wajib Pajak Orang Pribadi Yang Melakukan Pekerjaan Bebas Yang Terdaftar Di KPP Pratama Semarang Tengah Satu). E- journal S1 Undip, 1(2), 1-11.

Qadir, Abdurrachman. (2001) Zakat: Dalam Dimensi Mahdah dan Sosial. Jakarta: Srigunting.

Resmi, Siti. (2009). Perpajakan: Teori dan Kasus (5th ed). Jakarta : Salemba Empat. Rivai. (2009) Kepemimpinan dan Perilaku Organisasi. Jakarta : Rajawali Press.

Soepatmo, RP Bentari (2001). Zakat dan PPh Perlu Aturan Lebih Lanjut. Hasil Internal Search. Jakarta : Bisnis Indonesia.

Suprayogi, Agus. (2011). Faktor-faktor Yang Mempengaruhi Keinginan Dan Preferensi Pengusaha Mikro Untuk Berzakat. Tesis. Universitas Indonesia.

Undang-undang Nomor 17 Tahun 2000 tentang Pajak Penghasilan.

Undang-undang Republik Indonesia Nomor 28 Tahun 2007 Tentang Perubahan Ketiga Atas Undang-undang Nomor 6 Tahun 1983 Tentang Ketentuan Umum dan Tata Cara Perpajakan.

Undang-undang Nomor 36 Tahun 2008 tentang Perubahan Keempat atas UU No. 7 tahun 1983 tentang PajakPenghasilan.

Undang-undang Nomor 38 Tahun 1999 tentang Pengelolaan Zakat. 